\title{
Investigation and Monitoring of Groundwater Level: Building Crack Near to IIUM Kuantan
}

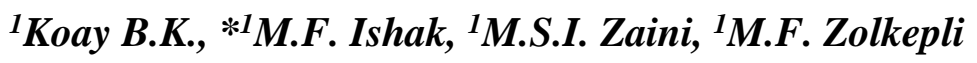 \\ ${ }^{1}$ Faculty of Engineering Technology, University Malaysia Pahang, 26300, Kuantan, Pahang, Malaysia \\ EEmail:fakhrurrazi@ump.edu.my
}

\begin{abstract}
The objective of this study is to analyze groundwater level on slope that effect the slope stability. In this research, the instrumentation monitoring equipment were applied to investigate the groundwater due to the rainfalls that effected to slope stability. Groundwater level were related to rainfall intensity and pore water pressure as the simulation of behavior of the groundwater pattern through slope model were produced. The result indicates that the pore water pressure and groundwater level are facilitated to be fluctuated by heavy rainfall. Moreover, the different part of slopes need to be compared and it was found that the bottom part of the slope has high concentration of groundwater and pore water pressure due to the rainfall cumulative effects. The result also indicates that the bottom slope is worse when it is subjected to a high groundwater level. Thus, the rising of groundwater level due to rainfall was the main reason for the slope resulted in unstable condition.
\end{abstract}

Index Terms- Groundwater, Piezometer, Slope stability, Rainfall intensity, Pore water pressure

\section{INTRODUCTION}

Groundwater system will change due to climate, ground-water withdrawal, and land use. The groundwater level measurement became source of information about how groundwater recharge, discharge and were store. For the long-term, the essential data related about the evaluation of change in groundwater level over time must be implemented. The water levels usually follow cyclic natural pattern and seasonal fluctuation in response to varying climatic conditions. So, the ground water level fluctuation results from seasonal variation of recharge.

The groundwater became one of the important factor in the slope stability analysis. According to Penman, 2002 and Kenneth, 2008, the effect of slope stability by groundwater normally associated with rainfall. Therefore, the rainfall infiltration result in large volume of water penetrating the soil then groundwater that may change which will lead to the soil becoming fully saturated on the slope. The changes in pore water pressure influenced by rainfall also produce direct impact to the behavior of soil on the slope which affect the effective stress of soils. The soil with high permeability were influenced by intense rainfall that make the excess pore-fluid pressure may be ignored but possibly have partly drained condition. Thus, intense rainfall will play an important role in slope failure occurrences.

The research is aimed to monitor the groundwater performances by using piezometer and rain gauge as assisting tool that helps to measure the water level. Dunnicliff, 1993 and Ridley, 1993 had stated that the piezometer became necessary instrument for the investigation. Moreover, the rainfall measurement must be implemented to expose better understanding in the variation of water level pattern. This study observed the accuracy of varying the water level to predict the actual saturated zone in the soil. The rainwater results also be tested and recorded to observe the variation of pore water pressure and groundwater level with time (days) by using rain water gauge. The effect of groundwater level and pore water pressure on the slope stability are explored and analyzed by using GEO STUDIO 2007 Software. The piezometric line as parameter of groundwater level is provided and used in 
subsequent stability analysis on the slope. The factor of safety (FOS) of the slope are then used to assess the slope stability.

The study area of this project focusing on the tropical residual soil slope. According to Ishak et. al., 2018, tropical residual soil is a product of chemical weathering, thus its characteristics are dependent on the environmental factors such as climate, parent rocks, age and topography. This type of soil can be found in most of the countries around the world, especially in the tropical region such as Malaysia.

\section{METHODOLOGY}

Initially, physical features (water content, specific gravity, grain size, liquid limit, plastic limit, compaction parameters, unconfined compressive strength test, permeability test) of clay sampling were tested based on the methodology to determine tropical residual soil by Ishak et. al., 2015. Afterwards, field studies were conducted by using piezometer intended to monitor the groundwater level while applied rain gauge device for collecting and measuring the amount of rain that falls. After that, the simulation of slope stability analysis is established by using Slope/W method of GEO-SLOPE 2007 software to help in assessing the FOS of slope whether slope is stable.

\section{SOIL CHARACTERISTICS AND PROFILES}

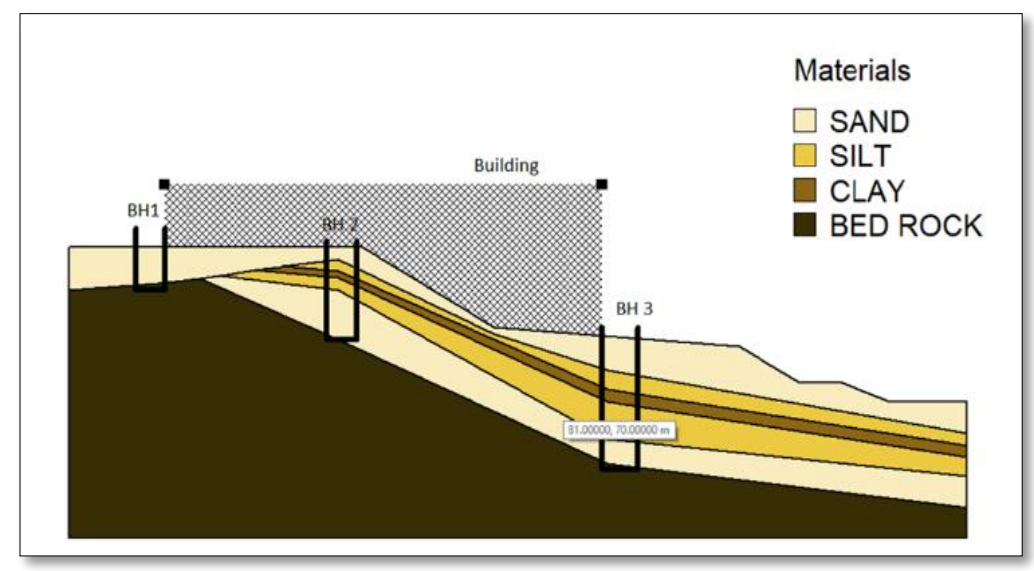

Figure 1: Soil Profile and Borehole Layout

According to the soil profile, the slope contains SAND, but some comprises of silty and little clay. Start from first depth at $3 \mathrm{~m}$ the slope is accumulated by sand containing very loose consistency. At upper part of slope, the bedrock is encountered early at the depth of $7.2 \mathrm{~m}$ which indicates that the upper part of slope is covered by sand along depth $7.2 \mathrm{~m}$. At middle part of slope, the slope accumulates sand for the first depth at $2 \mathrm{~m}$ and then the silt is encountered among depth $3.5 \mathrm{~m}$ to $7.5 \mathrm{~m}$ although clay also found at depth $5 \mathrm{~m}$. The sand is accumulated latterly $7.5 \mathrm{~m}$ and reach $15.60 \mathrm{~m}$ which encountered granite meet the bedrock. At the bottom part of slope, the sand is accumulated at top soil among depth $1.0 \mathrm{~m}$ to $2.0 \mathrm{~m}$. Later, the silt is found among depth $3.0 \mathrm{~m}$ to $18.0 \mathrm{~m}$ although the clay also is encountered among the depth of $7.5 \mathrm{~m}$ to $9.0 \mathrm{~m}$. The sand is encountered again at the depth of $18.0 \mathrm{~m}$ above and reach the depth of $19.50 \mathrm{~m}$ which encountered granite that indicate the location of the bedrock.

The upper part of slope contains low plasticity of soil indicate the sand has comprise low plasticity. This indicate that sand enable withstand the addition of considerable amounts of water, passing through a stage in which it remains dry and easy to be moulded. Next, the middle part and bottom part of slope have contained some silt and clay, therefore the result stated that the silt has high plasticity. This mean there are no high frictional resistance of the soil. Meanwhile, the soil which contained of silt and clay is easy to become wet and sticky and no longer maintains a moulded shape. Besides, the silt and clay also contain high moisture content on the middle part of slope which indicates that the middle part of 
slope contain higher compaction of soil due to lower dry density of soil compare with bottom part of slope. The middle part of slope generally more stable than bottom part of slope (Ishak, 2014).

From the result, it can be indicated that the clay and silt have higher cohesion strength than sand. So, the silt and clay generally contain higher shear force value compare to sand. The silt also indicated the highest unit weight of soil which concluded that the silt is denser and saturated. For friction angle, the sand contains high friction angle which explained that the sand is easy to be compacted while clay and silt can be considered as loose soil in the slope.

\section{THE EFFECT OF PORE WATER PRESSURE INDUCED BY RAINFALL}

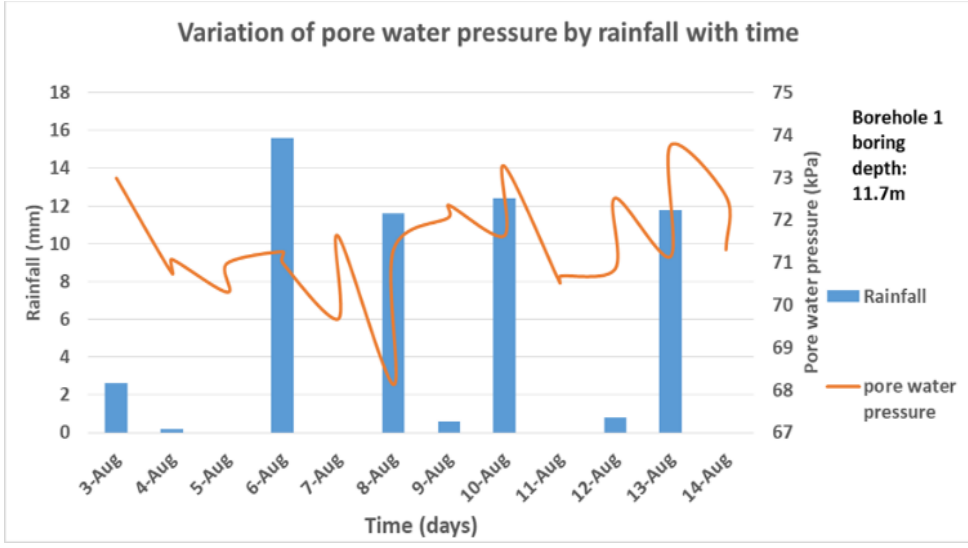

Figure 2 (a): Variation of Pore Water Pressure for Borehole 1

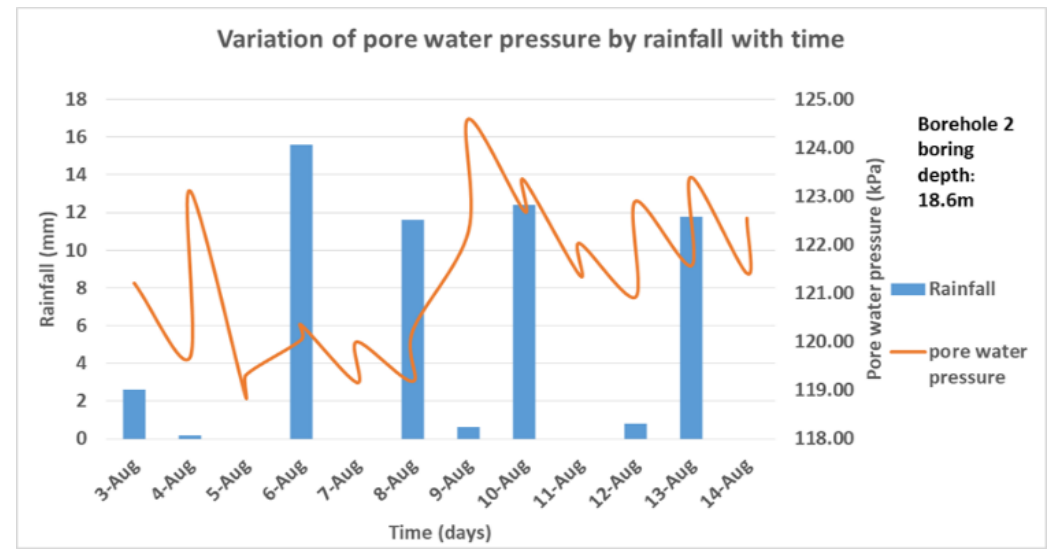

Figure 2 (b): Variation of Pore Water Pressure for Borehole 2

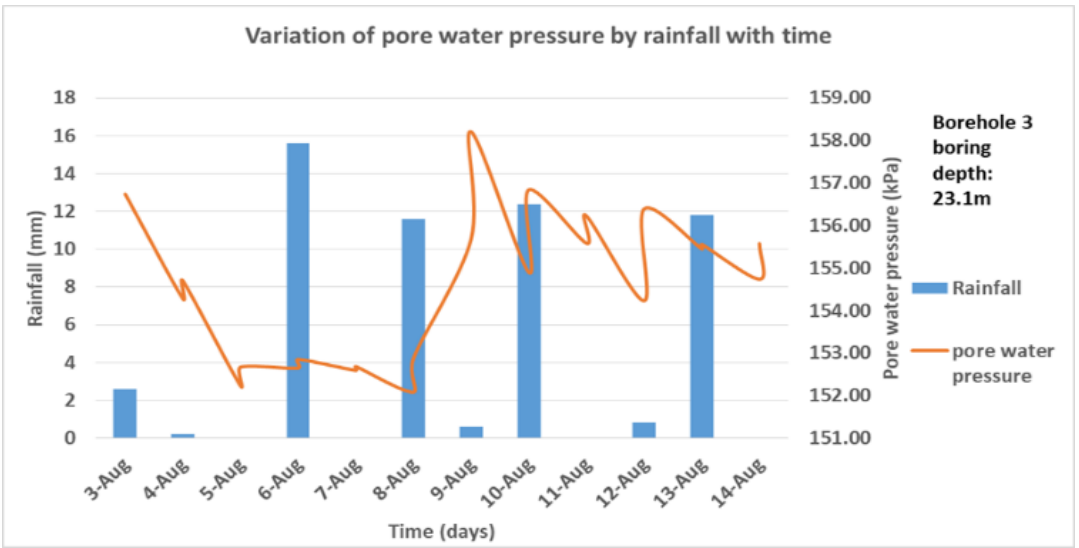

Figure 2 (c): Variation of Pore Water Pressure for Borehole 3 
From the graphs, the pore water pressure has apparently increase during the rainfall period. Due to the external stresses applied over the ground surface of the slope, the water easily penetrate into the soil which resulted in the increasing value of soil weight. Then the total stress (force) of the soil increase results the hydrostatic pressure increase. After dry period, the volume of water of the soil have become lower because of the expulsion of water from the soil. After certain equilibrium has been reached, the pore water pressure has change back to initial. When rainfall, the volume of water in the soil increase due to rainwater infiltration. In the high depth of well, the volume of water normally increases then water level increase causes the pore fluid not have chance to escape will lead to anomalously high formation pressures. From the graph of comparison of pore water pressure among 3 existing boreholes, there can found that the borehole 3 contain high value of pore water pressure due to contain high boring depth. This means there have high opportunity for water storage on borehole 3 that make the soil become saturated.

\section{VARIATION OF GROUNDWATER LEVEL}

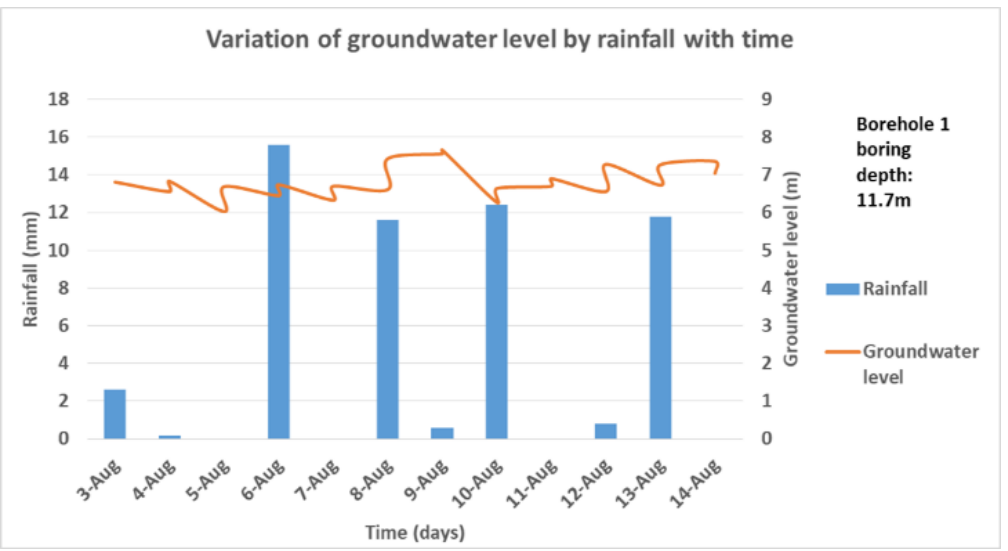

Figure 3 (a): Variation of Ground Water Level for Borehole 1

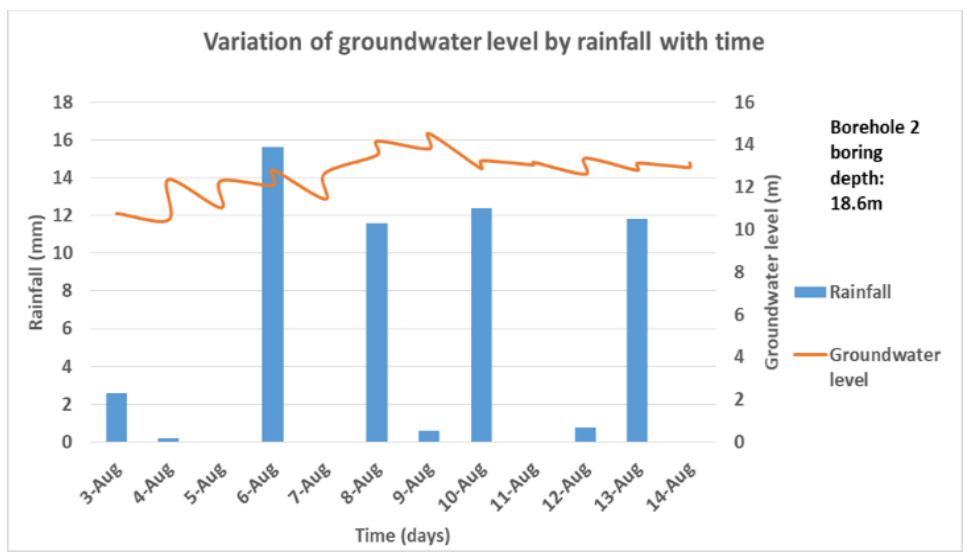

Figure 3 (b): Variation of Ground Water Level for Borehole 2 


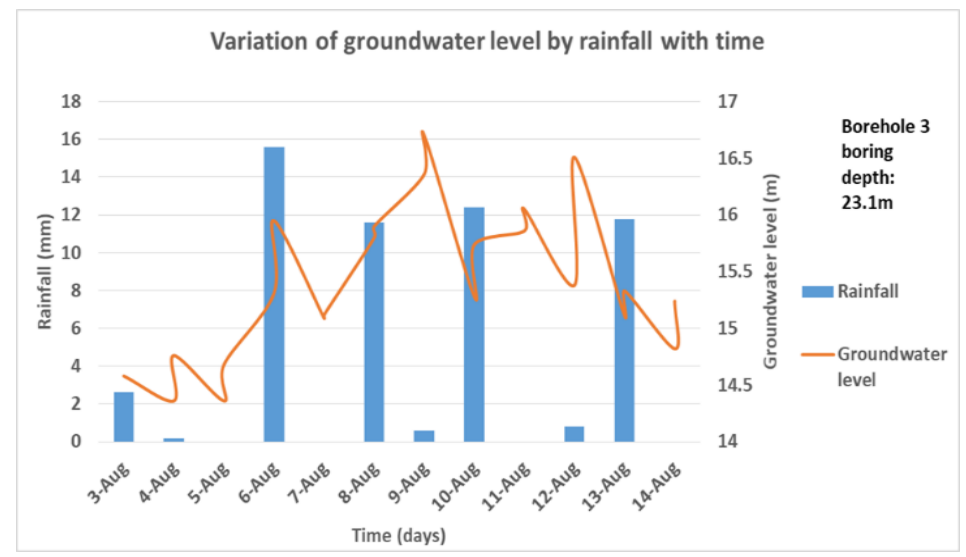

Figure 3 (c): Variation of Ground Water Level for Borehole 3

The trend showed that the groundwater level is induced by rainfall precipitation. The groundwater level presented a linear downward trend during dry period because of evaporation until recover to the initial groundwater level. The groundwater level increases the precipitation due to rainwater infiltration. Rainwater is infiltrated to the ground for certain period latterly resulting the water to recharge after the water reach the water table. Even though the rainfall value are at minimum value, the rainwater still accumulated and continue to infiltrate the ground which resulted the soil to become saturated (pore space of the soil filled with water infiltrated from the ground).The water is recharged and change the water level significantly. The groundwater level increase easily due to rapid recharged of heavy rainfall.

\section{CONCLUSIONS}

The effect of rainfall intensity and pore water pressure are studied to realize whether groundwater level is influenced. The rising of groundwater level due to the presence of rainfall intensity resulting change of pore water pressure and effect the slope become instability. When groundwater level fluctuated make the soil become saturated. The groundwater level increased through rainwater infiltration therefore slope stability is influenced by the deterioration of soil strength due to heavy rain induced. The slope become instability resulting the building failure is affected by the presence of crack.

\section{REFERENCES}

[1] Alley, W.M. (2001), Ground water and climate: Ground Water, Vol 39, no. 2, p. 161.

[2] Arthur Penman (2002). Measurement of Pore Water Pressures in Embankment Dams, pp 43-49.

[3] Bish, S \& Gates, G. (1994) In: Water Down Under 94: Groundwater/Surface Hydrology Common Interest Papers; Preprints of Papers. Barton, ACT: Institution of Engineers, Australia. pp. 399-403.

[4] Bishop, A.W., (1995) "The Use of theslip Circle in the Stability Analysis of Slope" Geotechnique, Vol. 5, pp. 7-17.

[5] Clough, G. W. and O'Rourke, T. D. (1990): Induced Movements of Insitu Walls. In Design and Performance of Earth Retaining Structures, ASCE Geotechnical Special Publications 25, pp. 439-470.

[6] Cole, C. A., R. P. Brooks, and D. H. Wardrop (1997). "Wetland Hydrology as a Function of Hydrogeomorphic (HGM) Subclass." Wetlands 17(4): pp 456-467.

[7] Daniel. M., (1999). Prediction of steady-state flow of real gases in randomly heterogeneous porous media. Physica D: Nonlinear Phenomena, Volume 1333, Issues 1-4, pp. 463-468.

[8] Dibiago E., Myrvoll F., Valstad T. \& Hansteen H. (1982),"Field Instrumentation, Observations and Performance Evaluations For the Svartvann Dam", 15th ICOLD, Rio de Janerio, pp 789-826.

[9] Dunnicliff, John (1993). Geotechnical Instrumentation for Monitoring Field Performance. Wiley-Interscience. p. 117

[10] Gavin Kenneth, \& Xue Jianfeng. (2008). "A simple method to analyze infiltration into unsaturated soil slopes". Computers and Geotechnics, 35(2), pp. 223-230. 
[11] Gibson R.E. (1963). Pore pressure equalization of piezometers in compressible soils. Geotechnique. Nol 31 , pp 105-123.

[12] Gilvear, D., and C. Bradley (2000). "Hydrological Monitoring and Surveillance for Wetland Conservation and Management; a UK Perspective." Phys. Chem. Earth (B) 25(7-8): pp 571- 588.

[13] Griffiths, D.V. and Lane, P.A. (1999). "Slope stability analysis by finite elements." Géotechnique, 49(3), pp. 387 - 403.

[14] Hvorslev, M.J. 1951. "Time Lag and Soil Permeability in Groundwater Observations."

[15] Ishak, M. (2014). Tree Water Uptake On Suction Distribution In Unsaturated Tropical Residual Soil Slope. Ph.D. Universiti Teknologi Malaysia.

[16] Ishak, M., Zolkepli, M. and Omardin, M. (2018). Tropical Residual Soil Properties on Slope. International Journal of Engineering Technology and Sciences (IJETS), Volume 8(1).

[17] LIN Hung-chou, YU Yu-zhen, \& LI Guang-xin. (2009). "Influence of rainfall characteristics on soil slope failure". Chinese Journal of Rock Mechanics and Engineering, 28(1), pp. 198-204.

[18] Moulin L, Gaume E, Obled C. (2009). Uncertainties on mean areal precipitation: assessment and impact on streamflow simulations. Hydrology and Earth System Sciences 13(2): pp 99-114.

[19] Myer, A.F, (1960). Effect of temperature on groundwater levels. Journal of Geophysical research 65, pp 1747-1752.

[20] Ridley AM and Burland JB (1993). A new instrument for the measurement of soil moisture suction. Géotechnique, vol 43, no 2, pp 321-324.

[21] Skalbeck, J. D., D. M. Reed, R. J. Hunt, and J. D. Lambert (2009). "Relating groundwater to seasonal wetlands in southeastern Wisonsin, USA.” Hydrogeology Journal 17: pp 215-228.

[22] Turk, L.J, (1975). Diurnal fluctuation of water tables induced by atmospheric pressure changes. Journal of Hydrology 26 (1-2), pp 1-16.

[23] Vaughan, P.R. (1969), A Note on Sealing Piezometers in Boreholes. Geotechnique, Vol. 19, No. 3, $405-413$.

[24] William F. Kane and Timothy J. Beck (2016) Instrumentation Practice For Slope Monitoring, "Engineering Geology Practice In Northern California" Association of Engineering Geologists publication, pp 1-20.

[25] Wilson, G., and Grace, H. (1942). The settlement of London due to under-drainage of the London Clay. J. Inst. Civil Engr. pp. 100-127.

[26] U Han, Zhu Yi-Wen, Cai Yuan-Qi, \& Zhu Fang-Min. (2005). "Stability analysis of unsaturated soil slopes under rainfall infiltration". Yantu Lixue (Rock and Soil Mechanics), 26(12), pp. 1957-1962.

[27] A. Dogan, H. Demirpence, and M. Cobaner (2008) "Prediction of groundwater levels from lake levels and climate data using ANN approach," Water SA, vol. 34, no. 2, pp. 199-208.

[28] Pirone, M., Damiano, E., Picarelli, L., Olivares, L., Urciuoli, G. (2012) Groundwater-atmosphere interaction in unsaturated pyroclastic slopes at two sites in Italy. Riv. Ital. Geotec. 46 (3), 29-49. 